\title{
Predicting the efficacy of Akt inhibitors using AutoDock Vina software
}

\author{
Mahmoud Ahmad Chawsheen \\ Faculty of Education, Soran University, Soran, Kurdistan Region, Iraq \\ Mahmoud.hassan@soran.edu.iq
}

\begin{abstract}
Akt is a serine/threonine protein kinase that has a central role in sustaining cell survival and growth in health and disease. In this study we aimed to uncover the best inhibitor, among the commercially available ones, for targeting Akt by predicting their specificity and potency using docking software AutoDock Vina. Our data revealed that the studied inhibitors had different energy requirements to perform successful docking with Akt, as Akti-1/2 inhibitor showed first highest docking score with $-15.2 \mathrm{kcal} / \mathrm{mol}$ and GSK 690693 inhibitor showed second highest docking sores with $-10.0 \mathrm{kcal} / \mathrm{mol}$. However, Perifosine showed the lowest docking scores with -7.5 $\mathrm{kcal} / \mathrm{mol}$. Interaction studies also confirmed that Akti-1/2, the inhibitor with the highest docking score, have been seen to build hydrogen bonds, build electrostatic and hydrophobic interactions and conquer the affinity of the most favorable binding pockets when bound with Akt. Due to their specific binding and potency, we recommend Akti-1/2 and GSK 690693 as the first and second best inhibitors for targeting Akt, respectively. Further in vitro and in vivo studies are required to confirm these results.
\end{abstract}

Keywords: Akt inhibitors, Akt, AutoDock Vina, cancer cells, cell signaling, Docking software.

\section{Introduction}

Akt is a serine/threonine protein kinase that plays a key role in regulation of several cellular signaling pathways. It is also known as protein kinase B (PKB) and considered as the main downstream target and the central node of the Phosphoinositide 3-kinase (PI3K) signaling cascade, which is in turn involved in cell growth, metabolism, proliferation, invasion, metastasis and angiogenesis (Brazil and Hemmings, 2001: Nicholson and Anderson, 2002: Franke, 2008: Cheung and Testa, 2013).

Akt consists of three domains: pleckstrin homology $(\mathrm{PH})$ domain at $\mathrm{N}$-terminal, a regulatory domain $(\mathrm{RD})$ at $\mathrm{C}$-terminal and a central kinase domain $(\mathrm{KD})$ (Thomas et al., 2002). In mammals, there are three conserved Akt isoforms (Akt1, Akt2 and Akt3) encoded by three separate genes. While there are structural similarities among 
these isoforms, they have different functions and expression profile among various organs of the body (Woodgett, 2005: Sahlberg et al., 2017).

Akt activation is triggered after stimulation of tyrosine kinase receptors by different ligands, e.g.: epidermal growth factor (EGF), platelet-derived growth factor (PDGF), basic fibroblast growth factor (bFGF) and insulin (Kohn et al., 1995: Okano et al., 2000: Razmara et al., 2013: Sun et al., 2013). Akt is activated by phosphorylation of T308 site of KD domain and S473 site of RD domain through phosphoinositidedependent protein kinases (PDKs) and mechanistic target of rapamycin complex 2 (mTORC2). When Akt is fully activated, via both phosphorylating sites, it will activates either pro- or anti-apoptotic signaling pathways via several intermediate effectors (Fayard et al., 2005: Song et al,. 2005:: Ersahin et al., 2015).

Akt is also known as the upstream target of mechanistic target of rapamycin complex 1 (mTORC1), FOXO, NFkB and Bcl-2 family proteins. These targets have central role in cell growth, survival and death (Manning and Cantley, 2007: Tzivion et al., 2011: Makinoshima et al., 2015). Akt's hyperactivation is found to be associated with evasion of apoptosis, increased cellular proliferation, and rapid metabolism (Hay, 2005: Sun et al., 2013) Several studies showed connection between increased Akt activation and tumor development in breast, prostate and pancreas (Altomare and Testa, 2005: Edlind and Hsieh, 2014). Moreover, Akt isoforms are playing different roles in cancer development. While Akt1 has a vital role in local tumor growth, Akt2 found to be involved in distant tumor spreading (Riggio et al., 2017).

From what was mentioned earlier, Akt represents an attractive target to eliminate cancer cell growth and metastasis. Since there are many inhibitors that can totally or partially inhibit Akt and then investigating each inhibitor will be both time consuming and expensive, thus software analysis may help to reduce the list of the available inhibitors. This can be accomplished by predicting their efficacy using computer software, which may be more beneficial in terms of improving the survival of more cancer patients by reaching an efficient combination for their treatment. In this study we tried to uncover the most potent and specific inhibitor from the commercially available ones to target Akt protein kinase using docking software AutoDock Vina.

\section{Materials and Methods}

\subsection{Preparation of Akt and inhibitors}

The crystal structures of Akt (PDB-ID: 3O96) were obtained from the RCSB Protein Data Bank (PDB) (http://www.rcsb.org) (Berman, 2000). Akt was separately prepared as a receptor and the inhibitors were also separately prepared as ligands using Discovery Studio 4.1 software (http://accerys.com) (Dassault Systèmes, 2016). Molecular Graphics Laboratory (MGL) Tools 1.5.6 (http://mgltools.scripps.edu) was 
used to prepare protein structures for molecular docking and polar hydrogens were added to these structures and saved in (PDBQT) file format (MGLTools, 2017).

In present study, a total of 9 Akt inhibitors were investigated (Table 1). The structures of most inhibitors were obtained from: https://pubchem.ncbi.nlm.nih.gov/ and all of them were verified by the supplier Tocris Bioscience (www.tocris.com). Some 2D structures were drawn by ChemDraw Pro 12.0 (www.cambridgesoft.com) and saved as (.mol) files (PerkinElmer, 2009). The 2D structures shown in Figure 1 were converted to 3D structures using Discovery Studio 4.1 (http://accerys.com) (Dassault Systèmes, 2016) and UCSF Chimera Ver. 1.10.1 program (http://www.cgl.ucsf.edu/chimera/) used to view these structures (Pettersen et al, 2004). Finally, all of the structures were converted to (.pdbqt) file format by Open Babel graphical user interface (GUI) (http://openbabel.org/) (O'Boyle et al., 2011).

\subsection{AutoDock Vina}

The docking site for the inhibitors on Akt was defined by establishing a cube that involved manipulating a colored box $(\mathrm{x}, \mathrm{y}, \mathrm{z})$ into that area, which included a docking stage. The volume of this box is flexible and can be changed as required, but at the same time increasing its volume will cause exponential increase in computational time. In our docking experiments, we used $24 \times 24 \times 24 \AA$ dimensions to cover the inhibitor binding site with a grid point spacing of $1.0 \AA$ and center grid boxes of 8.2, 7.4 and 11 in $\mathrm{X}, \mathrm{Y}$ and $\mathrm{Z}$ dimensions, respectively. Once the docking area has been defined, the coordinates of the grid box was written in a configuration file, a text document file, which was required to feed the AutoDock Vina 1.1.2 (Trott and Olson, 2010). The configuration file also specified the inhibitor (ligand) molecule, the Akt (receptor) to dock into and the exhaustiveness of the search which can be set between 1 and 8 (where 1 is the least and 8 is the most exhaustive search) (Trott and Olson, 2010). AutoDock Vina was run on the Windows 8.1 operating system with 4 CPUs and all Akt inhibitors were docked into the Akt three times.

\section{Results}

After generating a successful docking protocol, all Akt inhibitors were well docked into Akt proteins through Akt active site. Our results revealed that Akt inhibitors witnessed different affinities toward Akt protein, as they showed the following docking scores: Akti-1/2 (-15.2 kcal/mol), GSK 690693 (-10.0 kcal/mol), SC 66 (-9.7 $\mathrm{kcal} / \mathrm{mol})$, FPA 124 (-9.4 kcal/mol), 10-DEBC hydrochloride $(9.2 \mathrm{kcal} / \mathrm{mol})$, API-1 ($8.6 \mathrm{kcal} / \mathrm{mol})$, API-2 (-8.6 kcal/mol), PHT $427(-8.4 \mathrm{kcal} / \mathrm{mol})$ and Perifosine $(-7.5$ $\mathrm{kcal} / \mathrm{mol}$ ) (Table 2). Akti-1/2 inhibitor which showed highest docking score formed: hydrogen bond, electrostatic and hydrophobic interactions and conquered the affinity of the most favorable binding pockets as well. Hydrogen bond interactions were with residues: Asn54, Ser205 and Lys268, electrostatic interactions were with: Arg273 
and Asp292 and hydrophobic interactions were with: Trp80, Ile84, Arg86, Leu210, Leu264, Lys268, Val270 and Arg273 (Figure 2). GSK 690693 inhibitor which showed second highest docking score formed: hydrogen bond, unfavorable non-bond and hydrophobic interactions. Hydrogen bond interactions were with residues: Ser205 and Thr211. Unfavorable non-bond H-donor were with Asn53 and H-acceptor with Asn54. Hydrophobic interactions were with Trp80, Leu264, Val270 and Tyr272 (Figure 3).

\section{Discussion}

Docking studies predicted the interactions of examined inhibitors with Akt residues involved in this complex. In these interactions the most important requirements were a proper orientation and conformation fitting between the Akt binding site and the formed protein-ligand complex. Thus optimal interactions and the best Autodock Vina scores were used as criteria to understand the best conformation output among the 9 studied inhibitors. Docking results generated by AutoDock Vina program also helped in understanding possible docking interactions of inhibitors with Akt. Among the top-ranked modes between the studied inhibitors and Akt binding sites, Akti-1/2 provided gave maximum docking energy in negative (-ve), which was $-15.2 \mathrm{kcal} / \mathrm{mol}$ and accordingly it was found to be the best selective Akt inhibitor among the recommended ones (Table 2 and Figure 2). The second docking scores showed in GSK 690693 inhibitor which provided $-10.0 \mathrm{kcal} / \mathrm{mol}$, thus it was found to be the second best selective inhibitor for Akt among the recommended ones (Table 2 and Figure 3).

\section{Conclusions}

Among all of the studied Akt inhibitors, Akti-1/2 and GSK 690693 were the first and second best inhibitors for targeting Akt protein kinase, respectively. Beside electrostatic (only for Akt-1/2) and hydrophobic interactions that took place in Akt binding pockets, both inhibitors interacted with Akt by building hydrogen bonds with binding pocket residues. Conducting Molecular Dynamic Simulations is necessary to have a better understanding for dynamic behaviors and stability of predicted complexes. In vitro and in vivo investigations and proteomic profiling are required to uncover the impact of these inhibitors on living cells and their fate within living system.

\section{Acknowledgements}

I would like to acknowledge Mr. Hazem Abbas Al-Bustany at the College of Medicine, Hawler Medical University for his support during this project.

\section{Conflict of Interest}

There is no conflict of interest 


\section{References}

1. AltOMARE, D. A. \& TESTA, J. R. 2005. Perturbations of the AKT signaling pathway in human cancer. Oncogene, 24, 7455-64.

2. BARNETT, S. F., DEFEO-JONES, D., FU, S., HANCOCK, P. J., HASKELL, K. M., JONES, R. E., KAHANA, J. A., KRAL, A. M., LEANDER, K., LEE, L. L., MALINOWSKI, J., MCAVOY, E. M., NAHAS, D. D., ROBINSON, R. G. \& HUBER, H. E. 2005. Identification and characterization of pleckstrin-homology-domain-dependent and isoenzymespecific Akt inhibitors. Biochem J, 385, 399-408.

3. BARVE, V., AHMED, F., ADSUlE, S., BANERJEE, S., KULKARNI, S., KATIYAR, P., ANSON, C. E., POWELl, A. K., PADHYE, S. \& SARKAR, F. H. 2006. Synthesis, molecular characterization, and biological activity of novel synthetic derivatives of chromen4-one in human cancer cells. J Med Chem, 49, 3800-8.

4. BERMAN, H. M. 2000. The Protein Data Bank. Nucleic Acids Research, 28, 235-242.

5. BRAZIL, D. P. \& HEMMINGS, B. A. 2001. Ten years of protein kinase B signalling: a hard Akt to follow. Trends Biochem Sci, 26, 657-64.

6. CHEUNG, M. \& TESTA, J. R. 2013. Diverse mechanisms of AKT pathway activation in human malignancy. Curr Cancer Drug Targets, 13, 234-44.

7. DELGADO-RAMIREZ, M., MORAN-ZENDEJAS, R., ARECHIGA-FIGUEROA, I. A., TORO-CASTILLO, C., RAMIREZ-MARTINEZ, J. F. \& RODRIGUEZ-MENCHACA, A. A. 2016. Modulation of the voltage-gated potassium channel Kv2.1 by the anti-tumor alkylphospholipid perifosine. Pharmacol Rep, 68, 457-61.

8. EDLIND, M. P. \& HSIEH, A. C. 2014. PI3K-AKT-mTOR signaling in prostate cancer progression and androgen deprivation therapy resistance. Asian J Androl, 16, 378-86.

9. ERSAHIN, T., TUNCBAG, N. \& CETIN-ATALAY, R. 2015. The PI3K/AKT/mTOR interactive pathway. Mol Biosyst, 11, 1946-54.

10. FAYARD, E., TINTIGNAC, L. A., BAUDRY, A. \& HEMMINGS, B. A. 2005. Protein kinase B/Akt at a glance. J Cell Sci, 118, 5675-8.

11. FRANKE, T. F. 2008. PI3K/Akt: getting it right matters. Oncogene, 27, 6473-88.

12. HAY, N. 2005. The Akt-mTOR tango and its relevance to cancer. Cancer Cell, 8, 179-83.

13. HUANG, B. X., AKBAR, M., KEVALA, K. \& KIM, H.-Y. 2011. Phosphatidylserine is a critical modulator for Akt activation. The Journal of Cell Biology, 192, 979-992.

14. JO, H., LO, P. K., LI, Y., LOISON, F., GREEN, S., WANG, J., SILBERSTEIN, L. E., YE, K., CHEN, H. \& LUO, H. R. 2011. Deactivation of Akt by a small molecule inhibitor targeting pleckstrin homology domain and facilitating Akt ubiquitination. Proc Natl Acad Sci U S A, 108, 6486-91.

15. KIM, D., SUN, M., HE, L., ZHOU, Q. H., CHEN, J., SUN, X. M., BEPLER, G., SEBTI, S. M. \& CHENG, J. Q. 2016. A small molecule inhibits Akt through direct binding to Akt and preventing Akt membrane translocation. J Biol Chem, 291, 22856.

16. KOHN, A. D., KOVACINA, K. S. \& ROTH, R. A. 1995. Insulin stimulates the kinase activity of RAC-PK, a pleckstrin homology domain containing ser/thr kinase. EMBO J, 14, 4288-95.

17. MAKINOSHIMA, H., TAKITA, M., SARUWATARI, K., UMEMURA, S., OBATA, Y., ISHII, G., MATSUMOTO, S., SUGIYAMA, E., OCHIAI, A., ABE, R., GOTO, K., ESUMI, H. \& TSUCHIHARA, K. 2015. Signaling through the Phosphatidylinositol 3-Kinase (PI3K)/Mammalian Target of Rapamycin (mTOR) Axis Is Responsible for Aerobic 
Glycolysis mediated by Glucose Transporter in Epidermal Growth Factor Receptor (EGFR)mutated Lung Adenocarcinoma. J Biol Chem, 290, 17495-504.

18. MANNING, B. D. \& CANTLEY, L. C. 2007. AKT/PKB signaling: navigating downstream. Cell, 129, 1261-74.

19. MEUILlET, E. J., ZUOHE, S., LEMOS, R., IHLE, N., KINGSTON, J., WATKINS, R., MOSES, S. A., ZHANG, S., DU-CUNY, L., HERBST, R., JACOBY, J. J., ZHOU, L. L., AHAD, A. M., MASH, E. A., KIRKPATRICK, D. L. \& POWIS, G. 2010. Molecular pharmacology and antitumor activity of PHT-427, a novel Akt/phosphatidylinositidedependent protein kinase 1 pleckstrin homology domain inhibitor. Mol Cancer Ther, 9, 70617.

20. MGLTOOLS. 2017. Molecular Graphics Laboratory Tools [Online]. The Olson Laboratory. Available: http://mgltools.scripps.edu/ [Accessed 01/08/2017 2017].

21. NICHOLSON, K. M. \& ANDERSON, N. G. 2002. The protein kinase B/Akt signalling pathway in human malignancy. Cell Signal, 14, 381-95.

22. O'BOYLE, N. M., BANCK, M., JAMES, C. A., MORLEY, C., VANDERMEERSCH, T. \& HUTCHISON, G. R. 2011. Open Babel: An open chemical toolbox. Journal of Cheminformatics, 3, 33.

23. OKANO, J., GASLIGHTWALA, I., BIRNBAUM, M. J., RUSTGI, A. K. \& NAKAGAWA, H. 2000. Akt/protein kinase B isoforms are differentially regulated by epidermal growth factor stimulation. J Biol Chem, 275, 30934-42.

24. PERKINELMER. 2009. ChemDraw Professional [Online]. PerkinElmer Inc. Available: http://www.cambridgesoft.com/Ensemble_for_Chemistry/ChemDraw/ChemDrawProfessiona 1/Default.aspx [Accessed 01/07/2017 2017].

25. PETTERSEN, E. F., GODDARD, T. D., HUANG, C. C., COUCH, G. S., GREENBLATT, D. M., MENG, E. C. \& FERRIN, T. E. 2004. UCSF Chimera--a visualization system for exploratory research and analysis. J Comput Chem, 25, 1605-12.

26. RAZMARA, M., HELDIN, C. H. \& LENNARTSSON, J. 2013. Platelet-derived growth factor-induced Akt phosphorylation requires mTOR/Rictor and phospholipase C-gamma1, whereas S6 phosphorylation depends on mTOR/Raptor and phospholipase D. Cell Commun Signal, 11, 3.

27. RHODES, N., HEERDING, D. A., DUCKETT, D. R., EBERWEIN, D. J., KNICK, V. B., LANSING, T. J., MCCONNELL, R. T., GILMER, T. M., ZHANG, S. Y., ROBELL, K., KAHANA, J. A., GESKE, R. S., KLEYMENOVA, E. V., CHOUDHRY, A. E., LAI, Z., LEBER, J. D., MINTHORN, E. A., STRUM, S. L., WOOD, E. R., HUANG, P. S., COPELAND, R. A. \& KUMAR, R. 2008. Characterization of an Akt kinase inhibitor with potent pharmacodynamic and antitumor activity. Cancer Res, 68, 2366-74.

28. RigGiO, M., PERRONE, M. C., POLO, M. L., RODRIGUEZ, M. J., MAY, M., ABBA, M., LANARI, C. \& NOVARO, V. 2017. AKT1 and AKT2 isoforms play distinct roles during breast cancer progression through the regulation of specific downstream proteins. Sci Rep, 7, 44244.

29. SAHLBERG, S. H., MORTENSEN, A. C., HAGLÖF, J., ENGSKOG, M. K. R., ARVIDSSON, T., PETTERSSON, C., GLIMELIUS, B., STENERLÖW, B. \& NESTOR, M. 2017. Different functions of AKT1 and AKT2 in molecular pathways, cell migration and metabolism in colon cancer cells. International Journal of Oncology, 50, 5-14.

30. SONG, G., OUYANG, G. \& BAO, S. 2005. The activation of Akt/PKB signaling pathway and cell survival. $J$ Cell Mol Med, 9, 59-71. 
31. SUN, B., XU, H., ZHANG, G., ZHU, Y., SUN, H. \& HOU, G. 2013. Basic fibroblast growth factor upregulates survivin expression in hepatocellular carcinoma cells via a protein kinase B-dependent pathway. Oncol Rep, 30, 385-90.

32. SYSTÈMES, D. 2016. Discovery Studio Modeling Environment. 4.1 ed. San Diego: Dassault Systèmes.

33. THIMMAIAH, K. N., EASTON, J. B., GERMAIN, G. S., MORTON, C. L., KAMATH, S., BUOLAMWINI, J. K. \& HOUGHTON, P. J. 2005. Identification of N10-substituted phenoxazines as potent and specific inhibitors of Akt signaling. J Biol Chem, 280, 31924-35.

34. THOMAS, C. C., DEAK, M., ALESSI, D. R. \& VAN AALTEN, D. M. F. 2002. HighResolution Structure of the Pleckstrin Homology Domain of Protein Kinase B/Akt Bound to Phosphatidylinositol (3,4,5)-Trisphosphate. Current Biology, 12, 1256-1262.

35. TROTT, O. \& OLSON, A. J. 2010. AutoDock Vina: improving the speed and accuracy of docking with a new scoring function, efficient optimization, and multithreading. J Comput Chem, 31, 455-61.

36. TZIVION, G., DOBSON, M. \& RAMAKRISHNAN, G. 2011. FoxO transcription factors; Regulation by AKT and 14-3-3 proteins. Biochim Biophys Acta, 1813, 1938-45.

37. WOODGETT, J. R. 2005. Recent advances in the protein kinase B signaling pathway. Curr Opin Cell Biol, 17, 150-7.

38. YANG, L., DAN, H. C., SUN, M., LIU, Q., SUN, X. M., FELDMAN, R. I., HAMILTON, A. D., POLOKOFF, M., NICOSIA, S. V., HERLYN, M., SEBTI, S. M. \& CHENG, J. Q. 2004. Akt/protein kinase B signaling inhibitor-2, a selective small molecule inhibitor of Akt signaling with antitumor activity in cancer cells overexpressing Akt. Cancer Res, 64, 4394-9.

Table 1: List of verified Akt inhibitors

\begin{tabular}{lcccc}
\hline$\#$ & AKT Inhibitors & CID & CAS No. & References \\
\hline 1 & Akti-1/2 & 10196499 & $612847-09-3$ & Barnett et al. (2005) \\
2 & API-1 & 24773090 & $36707-00-3$ & Kim et al. (2016) \\
3 & API-2 & 65399 & $35943-35-2$ & Yang et al. (2004) \\
4 & 10-DEBC hydrochloride & 10521421 & $925681-41-0$ & Thimmaiah et al. (2005) \\
5 & FPA 124 & 56972210 & $902779-59-3$ & Barve et al. (2006) \\
6 & GSK 690693 & 16725726 & $937174-76-0$ & Rhodes et al. (2008) \\
7 & Perifosine & 148177 & $157716-52-4$ & Delgado-Ramírez et al. (2016) \\
8 & PHT 427 & 44240850 & $1191951-57-1$ & Meuillet et al. (2010) \\
9 & SC 66 & 6018993 & $871361-88-5$ & Jo et al. (2011) \\
\hline
\end{tabular}


Table 2: Average docking scores for inhibitors docked into Akt

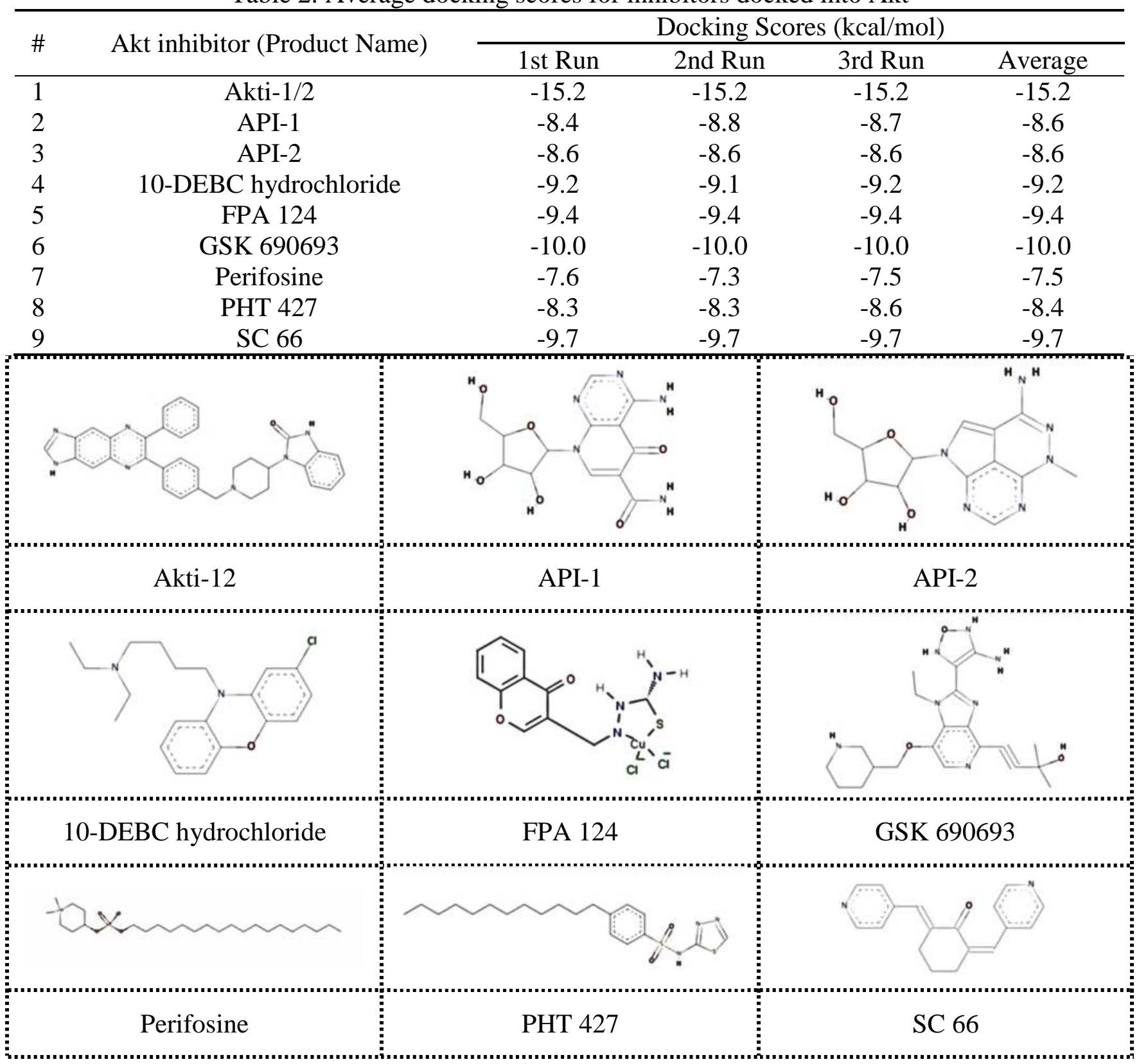

Figure 1: Diagrams showing 2D structures of Akt inhibitors used in the present study. 


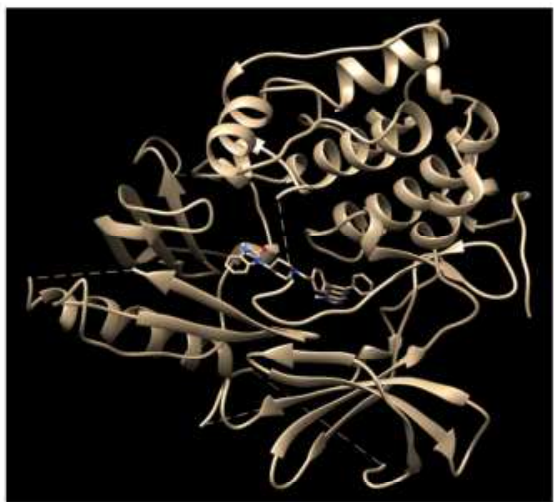

(a)

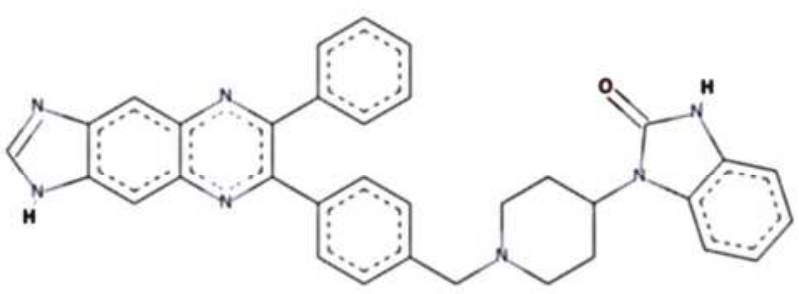

(b)

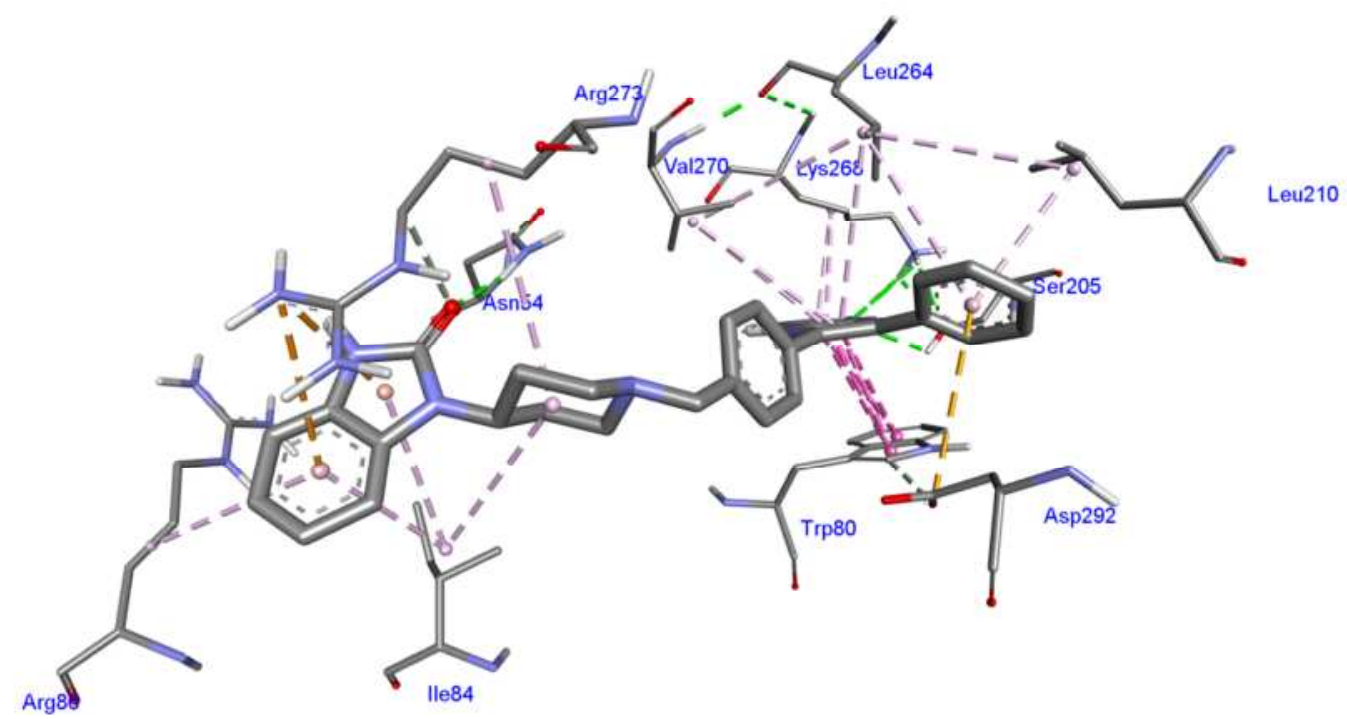

(c)

Figure 2: Inhibitors Akti-1/2 docked into Akt protein. (a) Shows the protein as ribbons and the inhibitor in its active site, (b) 2D of inhibitor Akti-1/2 and (c) shows interaction of the residues of the protein with the inhibitor. 


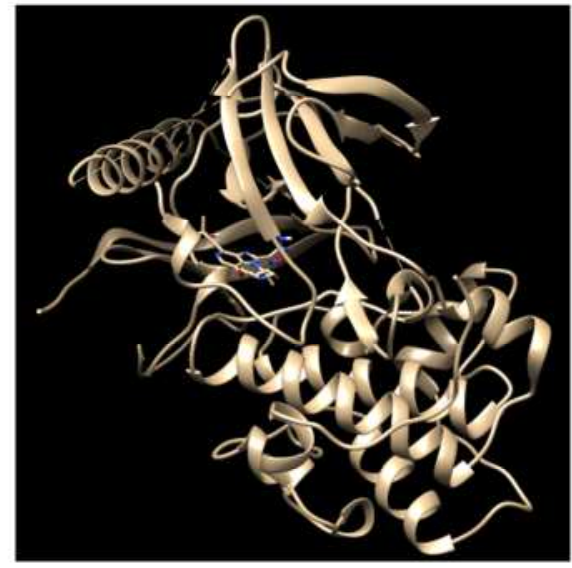

(a)

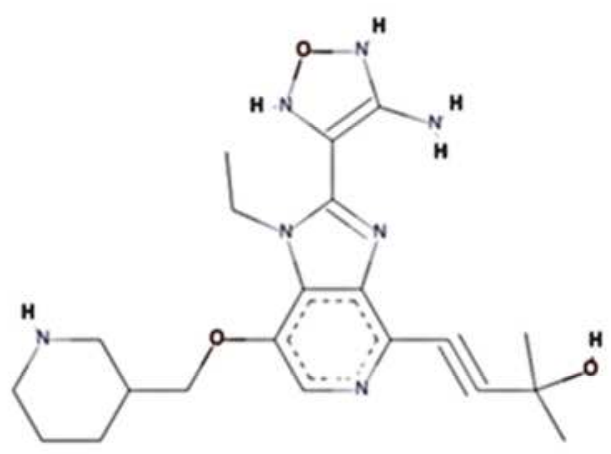

(b)

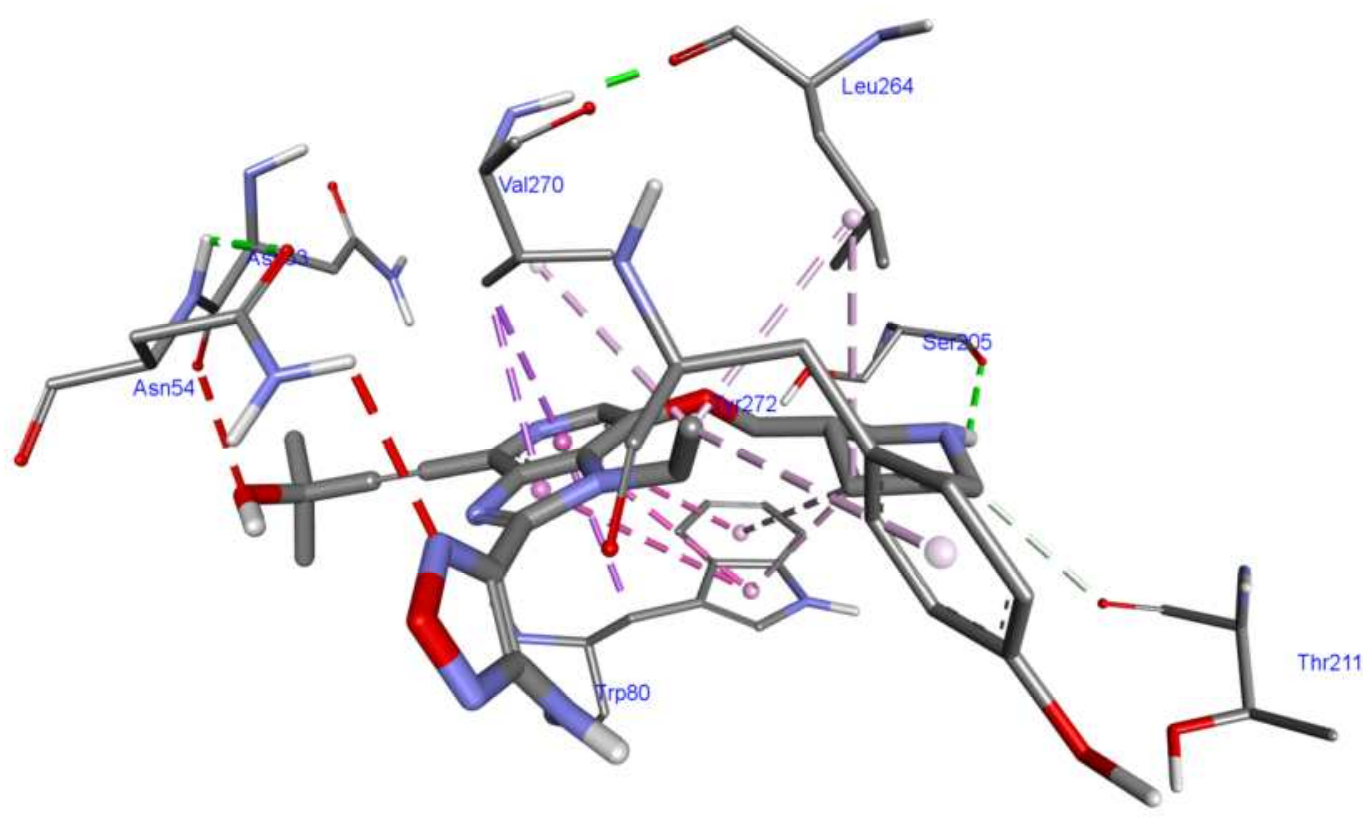

(c)

Figure 3: Inhibitor GSK 690693 docked into Akt protein. (a) Shows the protein as ribbons and the inhibitor in its active site, (b) 2D of inhibitor GSK 690693 and (c) shows interaction of the residues of the protein with the inhibitor. 